\title{
Vladimir Mikhailovich Zhukovsky
}

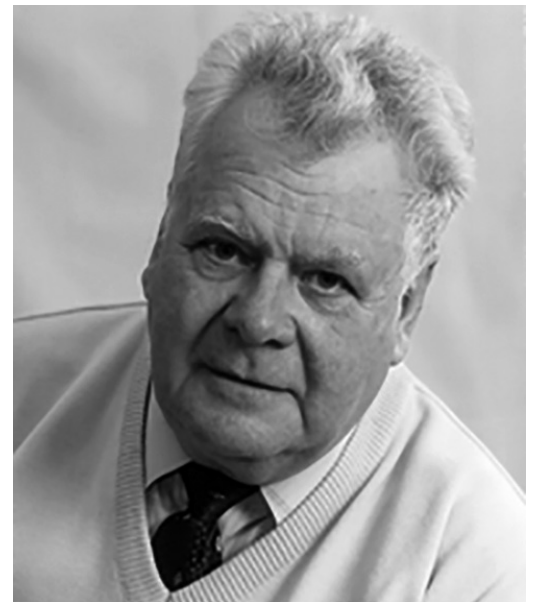

Vladimir Mikhailovich Zhukovsky was born on 13 may 1931 in the town of Spas-Demensk, Kaluga region. He finished school in the Urals, and then entered the first set of physical-technical faculty of UPI (Sverdlovsk), which he graduated in 1955, and in 1962 he was postgraduate student of the Ural Polytechnic Institute (UPI). He started Engineering activities in the nuclear industry at the oldest Russian radiochemical plant. In 1957 he entered into one of the first groups of the liquidators.

From 1963 his work was related to the chemical faculty of the Ural State University, where he passed the way from a candidate of sciences, associate professor to the doctor of chemical sciences, professor. During the 4 years he was the dean of the chemical faculty, during 11 years he was the pro-rector for scientific work, during 15 years old he was the Head department of analytical chemistry. Zhukovsky V. M. developed and or the first time read the courses in the field of physical chemistry, chemical, statistical and nonequilibrium thermodynamics, physical chemistry and technology of solids, crystal chemistry, chemical metrology and analytical control, standardization and certification.

For the conception of teaching of the natural sciences to the humanities, V. M. Zhukovskiy in the team of authors was awarded the winner of the prize of the President of the Russian Federation of 2000 in the field of education.

The extensive scientific school and the academic specialization in solid state chemistry has established by Vladimir Mikhailovich in the Ural University. It was started in the mid $60^{\text {th }}$ of XX century, when the Department of physical chemistry of the Ural State University has been active in scientific terms, a creative team of researchers. The students, and since the mid 60-ies and the first graduate students A. N. Petrov, T. M. Yanushkevich, S. F. Wexler, N. A. Veselova were involved in the scientific research. 
In 1964 the first graduation works on the physical chemistry of solids were protected, and in 1965 the first experimental setup of thermal and thermogravimetric analysis were created. In the $70^{\text {th }}$ number studied in the group of oxide materials significantly increased - from traditional to the molybdates and tungstates of alkaline earth metals are added ferrites, niobates, vanadates, as well as the manganites, cobaltites, nicelty and cuprite of the rare earth elements and of the alkalineearth elements. Currently all of these lines of research are continued by his disciples, and the disciples of his disciples. In fact, in three of the five departments of the chemical faculty of the Institute of natural Sciences (analytical chemistry, physical chemistry, inorganic chemistry) of Ural Federal University the researches successfully conducted, undergraduate and graduate students in the field of chemistry of solids continued.

For more than 50 years of history, Zhukovsky V. M. together with the staff made fundamental studies of the thermodynamic and structural characteristics of oxide materials, made a significant contribution to the development of experimental and theoretical approaches to the description of transport and electrical properties of individual chemical compounds and solid solutions. Within the framework of the scientific school 10 doctors of Sciences and, more than
60 candidates of science were prepared. Vladimir Mikhailovich, his colleagues and students always support the creative scientific contacts with institutes of the RAS and number of leading universities in the field of solid state chemistry in Russia and abroad.

Vladimir Mikhailovich was the inspirer and permanent head of the visiting Winter school on solid state chemistry, traditional and well-known far beyond the Department of chemistry. In 2016 XXV anniversary, the School dedicated to his memory will be held.

Vladimir Mikhailovich was the shine lecturer, a renowned scholar and Teacher with a capital letter, deservedly earned the love and respect of others. His rich spiritual world, humanity, the desire to understand and help, the ability to interact on equal terms with young and venerable scientists, comprehensive erudition, scholarly integrity and openness always will be remembered by all who were lucky enough to be in touch with him on his life journey.

This edition of the magazine, which included articles by renowned experts in the field of solid state chemistry from Yekaterinburg, Novosibirsk, Ulan-Ude and St. Petersburg, is dedicated to the memory of Vladimir Mikhailovich Zhukovsky, which remains an example for us in science and life. 


\section{Владимир Михайлович Жуковский}

Отчизна, воля, тот горчайший дьм,

Что нас разбудит поздно или рано,

Но дай хоть раз заплакать покаянно:

«Учитель, перед именем твоим...»

Да разве сердие позабудет того, кто хочет нам добра, того, кто нас выводит в люди, кто нас выводит в мастера

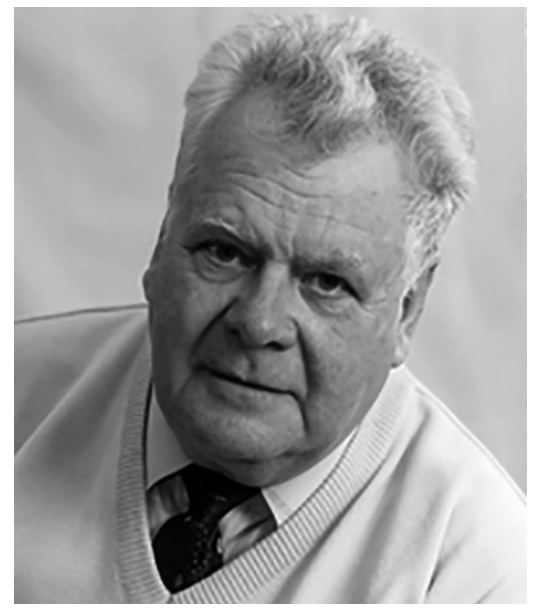

Владимир Михайлович Жуковский родился 13 мая 1931 года в г. СпасДеменске Калужской области. Школу оканчивал на Урале, затем поступил на физико-технического факультета УПИ (Свердловск), первый набор, который окончил в 1955 г. и в 1962 г. - аспирантуру Уральского политехнического института (УПИ). Инженерно-техническую деятельность начинал в атомной промышленности на старейшем в России радиохимическом заводе. В 1957 г. он входил в одну из первых групп ликвидаторов.

С 1963 г. его деятельность была связана с химическим факультетом Уральского государственного университета, где он прошел путь от кандидата наук, доцента до доктора химических наук, профессора. В течение четырех лет был деканом химического факультета, 11 лет - проректором университета по научной работе, 15 лет заведующим кафедрой аналитической химии. В. М. Жуковским разработаны и впервые прочитаны курсы в области физической химии, химической, статистической и неравновесной термодинамики, физикохимии и технологии твердого тела, кристаллохимии, химической метрологии и аналитического контроля, стандартизации и сертификации. За разработку концепции преподавания естествознания для гуманитариев В. М. Жуковский в числе коллектива авторов стал лауреатом Премии президента Российской Федерации 2000 г. в области образования.

Владимиром Михайловичем в Уральском университете создана разветвленная научная школа и учебная специализация по химии твердого тела. Начало ей было положено в середине 60-х гг. $\mathrm{XX}$ в., когда на кафедре физической химии УрГУ сложился активный в научном плане творческий коллектив исследователей. К научным изысканиям были привлечены студенты, а с се- 
редины 60-х гг. и первые аспиранты А. Н. Петров, Т. М. Янушкевич, С. Ф. Векслер, Н. А. Веселова. В 1964 г. были защищены первые дипломные работы по физической химии твердого тела, а в 1965 г. - созданы первые экспериментальные установки термического и термогравиметрического анализа. В 1970-е гг. существенно расширился круг изучаемых в группе оксидных материалов - к ставшим традиционными молибдатам и вольфраматам щелочноземельных металлов добавляются ферриты, ниобаты, ванадаты, а также манганиты, кобальтиты, никелаты и куприты редкоземельных элементов и щелочноземельных элементов. В настоящее время все эти направления исследований продолжаются его учениками и учениками его учеников. Фактически на трех из пяти кафедр химического факультета Института естественных наук (аналитической химии, физической химии, неорганической химии) Уральского федерального университета успешно проводятся научные исследования, обучаются студенты и аспиранты по направлению химии твердого тела.

За более чем 50-летнюю историю существования этого направления В. М. Жуковским совместно с сотрудниками выполнены фундаментальные исследования термодинамических и структурных характеристик оксидных материалов, сделан существенный вклад в разработку экспериментальных и теоретических подходов к описанию транспортных и электрических свойств индивидуальных химических соединений и твердых растворов. В рамках научной школы подготовлено 10 докторов наук, более 60 кандидатов наук. Владимир Михайлович, его коллеги и ученики постоянно поддерживают творческие научные контакты с институтами РАН и рядом ведущих в области химии твердого тела университетов России и дальнего зарубежья.

Владимир Михайлович был идейным вдохновителем и бессменным руководителем выездной Зимней школы по химии твердого тела, ставшей традиционной и известной далеко за пределами химического факультета. В 2016 г. состоится XXV юбилейная Школа, посвященная его памяти.

Владимир Михайлович - блестящий лектор, известный ученый и Учитель с большой буквы, заслуженно снискавший любовь и уважение окружающих. Его богатый духовный мир, человечность, стремление понять и помочь, способность на равных взаимодействовать как с молодыми, так и с маститыми учеными, всесторонняя эрудиция, научная принципиальность и открытость всегда останутся в памяти всех, кому посчастливилось соприкоснуться с ним на своем жизненном пути.

Это выпуск журнала, в который вошли статьи известных специалистов в области химии твердого тела из Екатеринбурга, Новосибирска, Улан-Удэ и Санкт-Петербурга, мы посвящаем памяти Владимира Михайловича Жуковского, который остается примером для нас в науке и жизни. 